\title{
Pathogenicity and Virulence of Pythium Species Obtained from Forest Nursery Soils on Douglas-Fir Seedlings
}

Jerry E. Weiland, Bryan R. Beck, and Anne Davis, United States Department of Agriculture - Agriculture Research Service, Horticultural Crops Research Laboratory, and Oregon State University, Department of Botany and Plant Pathology, Corvallis, OR 97331 \begin{abstract}
seedlings. Plant Dis. 97:744-748.
Pythium species are common soilborne oomycetes that occur in forest nursery soils throughout the United States. Numerous species have been described from nursery soils. However, with the exception of $P$. aphanidermatum, $P$. irregulare, $P$. sylvaticum, and $P$. ultimum, little is known about the potential for other Pythium species found in nursery soils to cause damping-off of tree seedlings. A greenhouse study was conducted to evaluate the pathogenicity and virulence of 44 Pythium isolates representing 16 species that were originally recovered from soil at three forest nurseries in Washington and Oregon. Seeds of Douglas-fir (Pseudotsuga menziesii) were planted into soil infested with each of the isolates. Seedling survival, the number of surviving seedlings with necrotic root lesions, and taproot length were evaluated 4 weeks later. Responses of Douglas-fir to inoculation varied significantly depending on Pythium species and isolate. Eight species $(P$.
\end{abstract}

Abstract

Weiland, J. E., Beck, B. R., and Davis, A. 2013. Pathogenicity and virulence of Pythium species obtained from forest nursery soils on Douglas-fir dissotocum, P. irregulare, P. aff. macrosporum, P. mamillatum, P. aff. oopapillum, $P$. rostratifingens, $P$. sylvaticum, and $P$. ultimum var. ultimum) significantly reduced the number of surviving seedlings compared to the noninoculated treatment. However, all Pythium species caused a greater percentage of seedlings to develop root lesions (total mean $40 \%$ ) than was observed from noninoculated seedlings (17\%). Taproot length varied little among Pythium treatments and was not a useful character for evaluating pathogenicity. Results confirm the ability of $P$. irregulare, $P$. mamillatum, and $P$. ultimum var. ultimum to cause damping-off of Douglas-fir seedlings, and are indicative that other species such as $P$. dissotocum, $P$. aff. macrosporum, $P$. aff. oopapillum, $P$. rostratifingens, and $P$. sylvaticum may also be responsible for seedling loss.
Approximately 200 million tree seedlings are produced annually by forest nurseries located in the western United States (California, Idaho, Montana, Oregon, and Washington) (1). The majority of the seedlings are sold as 1- or 2-year-old bareroot conifer seedlings and are used for reforestation, although some seedlings are sold to Christmas tree and ornamental nursery operations. Douglas-fir (Pseudotsuga menziesii) is the most commonly planted species and accounts for approximately 75 million of the seedlings sold by forest nurseries in the region (18).

Pythium species are frequently associated with damping-off of forest nursery seedlings and are considered one of the most important soilborne pathogens limiting seedling production in the Pacific Northwest (PNW) region of the United States (Idaho, Oregon, and Washington) and Canada $(1,12)$. Unfortunately, relatively little is known regarding the identity of regional Pythium species capable of causing disease. Four species have been commonly found in forest nurseries of the PNW: P. aphanidermatum, $P$. irregulare, P. mamillatum, and P. ultimum $(2,4)$. However, at least 15 other species are also present in nursery soils (18), and it is unknown whether any or all of these species can also cause dampingoff.

Management of soilborne pests and pathogens in bareroot forest nurseries of the PNW of the United States is primarily achieved by preplant fumigation with methyl bromide or dazomet $(3,6,19)$. Supplemental control is provided by periodic application of fungi-

Corresponding author: Jerry Weiland,

E-mail: Jerry.Weiland@ars.usda.gov

Accepted for publication 31 December 2012.

http://dx.doi.org/10.1094/PDIS-09-12-0895-RE

This article is in the public domain and not copyrightable. It may be freely reprinted with customary crediting of the source. The American Phytopathological Society, 2013. cides, such as mefenoxam. Forest nurseries may survey field soils prior to planting in order to determine whether damaging levels of soilborne pathogens are present and to decide if fumigation is necessary. In the case of Pythium, populations exceeding 100 propagules per gram of soil (ppg) are considered problematic $(1,7)$. However, it is unknown whether all Pythium species present in regional forest nursery soils are pathogenic to forest tree seedlings, or whether some proportion of the Pythium community is nonpathogenic $(1,3)$. Therefore, decisions to fumigate based on population counts alone may overestimate the amount of risk if nonpathogenic isolates are abundant, thereby resulting in the unnecessary application of fumigants and fungicides. If forest nursery managers could identify relative numbers of pathogenic and nonpathogenic Pythium species, they could better evaluate the need for treatment. The first step toward this goal is to identify those Pythium species present in the soil that are pathogenic to forest nursery seedlings and to determine if variation exists among isolates within Pythium species for pathogenicity and virulence.

In order to determine pathogenicity and evaluate the relative virulence of Pythium species and isolates found in forest nurseries, a greenhouse study was conducted using 44 Pythium isolates representing 16 Pythium species. These isolates were originally collected in 2008 during a survey of three forest nurseries (two in Oregon, one in Washington) to determine the diversity of Pythium species in nursery soils (18). The objective of this research was to assess the potential of Pythium species and isolates to reduce Douglas-fir seedling survival, cause root lesions, and reduce taproot length.

\section{Materials and Methods}

Isolate selection. Forty-four Pythium isolates were selected from the isolate collection of a previous survey (18) to represent the range of Pythium species obtained from the soils of three forest nurseries in Washington and Oregon (Table 1). Whenever possible, isolates that were representative of a particular species were also chosen to originate from each of the three nurseries in order to 
represent potential geographic variability. Isolates were originally obtained by one of three methods: leaf disk trapping using either rhododendron leaf disks or Douglas-fir needles (9), and soil-dilution plating of a soil solution onto PARP agar, a semiselective medium for Pythiaceous species (8). Pythium isolates were identified to species on the basis of DNA sequence from the internal transcribed spacer (ITS) region and confirmed by morphology according to methods described (18).

Inoculation method and experimental design. Inoculum for each isolate was produced in fungal spawn bags containing vermiculite amended with V8 juice as previously described (19). Briefly, each isolate was initially grown in a $20-\mathrm{ml}$ petri plate containing clarified $\mathrm{V} 8$ juice agar $\left(3.4 \mathrm{~g} \mathrm{CaCO}_{3}\right.$ mixed with $340 \mathrm{ml} \mathrm{V8}$ juice, filtered through eight layers of cheesecloth, then diluted 1:4 with distilled water and $17 \mathrm{~g}$ agar/liter) for 7 days at $20^{\circ} \mathrm{C}$. Colonized agar from each plate was then cut into approximate $1.5-\mathrm{cm}^{2}$ pieces and placed into a spawn bag (Fungi Perfecti, Olympia, WA) containing 2 liters of dilute, clarified V8 juice $(75 \mathrm{ml}$ clarified V8 juice prepared as above per liter of distilled water) and 3 liters of dry coarse vermiculite that had been autoclaved three times at $48-\mathrm{h}$ intervals. Spawn bags were incubated in the dark at $20^{\circ} \mathrm{C}$ for approximately 60 days, with weekly mixing by hand. Inoculum was then removed from the bags, air-dried for 3 days, and stored in resealable polyethylene bags at $20^{\circ} \mathrm{C}$ until used to infest soilless potting media for inoculation treatments.

For each isolate, soilless potting media was infested with inoculum to achieve 100 propagules per gram (ppg) of soilless media. The soilless potting media was a commercial blend of $60 \%$ sphagnum peat moss, $35 \%$ perlite, $5 \%$ washed sand, starter fertilizer, and wetting agent (OBC Northwest Seedling Mix \#1, OBC Northwest Inc., Canby, OR). Inocula and soilless potting media were mixed in a twin-shell dry blender for $8 \mathrm{~min}$ and placed into eight replicate $450-\mathrm{cm}^{3}$ polystyrene pots. All infested media was manually moistened until gravitational drainage was apparent, then allowed to incubate for 5 to 6 days, and finally moistened again $24 \mathrm{~h}$ prior to seeding.

Ten cold-stratified Douglas-fir seeds were sown at $0.32-\mathrm{cm}$ depth in each pot. Each of the 44 Pythium-isolate treatments, and a noninoculated (negative) control were arranged on greenhouse benches in a complete randomized block design with eight repli-

Table 1. Responses ${ }^{\mathrm{y}}$ of Douglas-fir seedlings to inoculation with 44 isolates of Pythium obtained from soil at three forest nurseries

\begin{tabular}{|c|c|c|c|c|c|}
\hline Isolate & Species & Nursery $^{z}$ & Mean no. seedlings (SE) & $\begin{array}{l}\text { Mean percent seedlings } \\
\text { with root lesions (SE) }\end{array}$ & $\begin{array}{l}\text { Mean taproot length } \\
\text { in } \mathrm{cm} \text { (SE) }\end{array}$ \\
\hline Control & - & - & $7.6(0.37) \mathrm{a}$ & $17(4.8) \mathrm{a}$ & $8.4(0.55) \mathrm{a}$ \\
\hline 41 & P. dissotocum & $\mathrm{C}$ & $6.4(0.57) \mathrm{a}$ & $35(5.6)$ & $8.1(0.46) \mathrm{a}$ \\
\hline 101 & P. dissotocum & A & $4.2(0.52)$ & $47(8.4)$ & $6.8(0.40)$ \\
\hline 45 & P. irregulare & A & $4.7(0.58)$ & $49(9.1)$ & $7.6(0.61) \mathrm{a}$ \\
\hline 69 & P. irregulare & $\mathrm{C}$ & $1.4(0.41)$ & $75(11.2)$ & $6.0(0.68)$ \\
\hline 104 & P. irregulare & A & $4.6(0.50)$ & $30(8.7) \mathrm{a}$ & $8.0(0.49) \mathrm{a}$ \\
\hline 130 & P. irregulare & $\mathrm{B}$ & $5.4(0.47)$ & $40(7.9)$ & $7.2(0.37) \mathrm{a}$ \\
\hline 187 & P. irregulare & A & $1.4(0.39)$ & $26(13.8) \mathrm{a}$ & $7.6(1.11) \mathrm{a}$ \\
\hline P101A & P. irregulare group III & A & $7.1(0.31) \mathrm{a}$ & 29 (4.3) a & $8.2(0.38) \mathrm{a}$ \\
\hline P106A & P. irregulare group III & A & $6.7(0.32) \mathrm{a}$ & $40(6.4)$ & $8.4(0.32) \mathrm{a}$ \\
\hline P112C & P. irregulare group III & A & $7.5(0.40) \mathrm{a}$ & $49(7.5)$ & $8.2(0.33) \mathrm{a}$ \\
\hline P137C & P. irregulare group IV & B & $7.6(0.27) \mathrm{a}$ & $40(6.6)$ & $8.6(0.36) \mathrm{a}$ \\
\hline P219B & P. irregulare group IV & A & $7.5(0.45) \mathrm{a}$ & $31(6.0) \mathrm{a}$ & $9.1(0.33) \mathrm{a}$ \\
\hline P228B & P. irregulare group IV & $\mathrm{B}$ & $7.6(0.32) \mathrm{a}$ & $46(7.9)$ & $8.3(0.40) \mathrm{a}$ \\
\hline 10 & P. aff. macrosporum & B & $2.5(0.53)$ & $58(10.1)$ & $6.3(0.72)$ \\
\hline 23 & P. aff. macrosporum & $\mathrm{C}$ & $7.2(0.40) \mathrm{a}$ & $38(6.7)$ & $7.8(0.40) \mathrm{a}$ \\
\hline 25 & P. aff. macrosporum & A & $1.2(0.47)$ & $23(13.5) \mathrm{a}$ & $7.1(2.27)$ \\
\hline D215C & P. mamillatum & A & $6.1(0.33)$ & $30(6.2) \mathrm{a}$ & $7.7(0.25) \mathrm{a}$ \\
\hline D266A & P. mamillatum & $\mathrm{C}$ & $4.4(0.56)$ & $46(7.5)$ & $7.5(0.54) \mathrm{a}$ \\
\hline P158A & P. mamillatum & $\mathrm{C}$ & $6.5(0.49) \mathrm{a}$ & $40(6.3)$ & $8.0(0.33) \mathrm{a}$ \\
\hline $\mathrm{R} 153 \mathrm{C}$ & P. aff. mercuriale & $\mathrm{C}$ & $7.9(0.38) \mathrm{a}$ & $45(5.1)$ & $9.1(0.45) \mathrm{a}$ \\
\hline D223A2 & P. middletonii & A & $7.8(0.26) \mathrm{a}$ & $34(5.6)$ & $7.9(0.28) \mathrm{a}$ \\
\hline 36 & P. middletonii & A & $6.4(0.43)$ & $29(6.0) \mathrm{a}$ & $8.7(0.31) \mathrm{a}$ \\
\hline D165B & P. aff. oopapillum & $\mathrm{C}$ & $5.9(0.62)$ & $44(8.7)$ & $7.8(0.42) \mathrm{a}$ \\
\hline D165C & P. aff. oopapillum & $\mathrm{C}$ & $5.2(0.60)$ & $44(6.9)$ & $7.0(0.52) \mathrm{a}$ \\
\hline 85 & P. pachycaule & A & $7.3(0.27) \mathrm{a}$ & $33(5.7)$ & $8.1(0.38) \mathrm{a}$ \\
\hline R121B & P. pachycaule & A & $7.6(0.45) \mathrm{a}$ & $48(6.0)$ & $9.1(0.41) \mathrm{a}$ \\
\hline 4 & P. rostratifingens & A & $4.5(0.57)$ & $45(8.9)$ & $8.0(0.53) \mathrm{a}$ \\
\hline 50 & P. rostratifingens & $\mathrm{C}$ & $6.7(0.41) \mathrm{a}$ & $36(7.3)$ & $7.8(0.29) \mathrm{a}$ \\
\hline 89 & P. aff. spiculum & $\mathrm{C}$ & $6.8(0.57) \mathrm{a}$ & $51(7.9)$ & $7.6(0.38) \mathrm{a}$ \\
\hline 94 & P. aff. spiculum & A & $5.8(0.47) \mathrm{a}$ & $37(7.4)$ & $7.5(0.36) \mathrm{a}$ \\
\hline P149A & P. aff. spiculum & $\mathrm{C}$ & $7.0(0.41) \mathrm{a}$ & $50(6.4)$ & $8.4(0.35) \mathrm{a}$ \\
\hline 194 & P. sylvaticum & $\mathrm{B}$ & $3.7(0.49)$ & $48(7.6)$ & $7.5(0.48) \mathrm{a}$ \\
\hline syl A2-3 & P. sylvaticum & B & $6.4(0.51)$ & $40(7.3)$ & $8.0(0.32) \mathrm{a}$ \\
\hline syl C1-4 & P. sylvaticum & $\mathrm{C}$ & $5.8(0.47)$ & 45 (7.9) & $8.2(0.39) \mathrm{a}$ \\
\hline 19 & P. torulosum & A & $5.5(0.68)$ & $49(7.8)$ & $7.5(0.46) \mathrm{a}$ \\
\hline P249A & P. torulosum & $\mathrm{C}$ & $7.9(0.27) \mathrm{a}$ & $45(6.4)$ & $9.1(0.34) \mathrm{a}$ \\
\hline R119D & P. torulosum & A & $7.8(0.39) \mathrm{a}$ & $32(5.5)$ & $8.5(0.36) \mathrm{a}$ \\
\hline $\mathrm{R} 215 \mathrm{~A}$ & P. torulosum & $\mathrm{C}$ & $7.8(0.25) \mathrm{a}$ & $25(5.7) \mathrm{a}$ & $8.3(0.34) \mathrm{a}$ \\
\hline 193 & P. ultimum var. ultimum & $\mathrm{C}$ & $5.5(0.39)$ & $52(7.1)$ & $8.1(0.44) \mathrm{a}$ \\
\hline ult A1-2 & P. ultimum var. ultimum & $\mathrm{B}$ & $5.8(0.44)$ & $33(5.3)$ & $8.6(0.34) \mathrm{a}$ \\
\hline ult C1-8 & P. ultimum var. ultimum & $\mathrm{C}$ & $3.0(0.55)$ & $38(5.1)$ & $7.1(0.78)$ \\
\hline 9 & $P$. 'vipa' & $\mathrm{B}$ & $8.0(0.33) \mathrm{a}$ & $40(6.1)$ & $8.3(0.45) \mathrm{a}$ \\
\hline D130A & P. 'vipa' & B & $7.8(0.33) \mathrm{a}$ & $35(6.9)$ & $8.1(0.40) \mathrm{a}$ \\
\hline D240C & P. 'vipa' & $\mathrm{B}$ & $7.5(0.36) \mathrm{a}$ & $41(6.9)$ & $8.6(0.48) \mathrm{a}$ \\
\hline
\end{tabular}

y Values represent response means for each isolate and are based on 10 Douglas-fir seeds planted in eight replicate pots in three separate trials arranged according to a random complete block design. $n=24$ pots. Data were collected 4 weeks after planting into noninfested soilless media (Control) or in media infested with one each of 44 Pythium isolates. Values in a column followed by the same letter are not significantly different from the control treatment at $P>0.05$.

${ }^{\mathrm{z}}$ Nursery A is located in Washington. Nurseries B and C are located in Oregon. 
cate blocks. Douglas-fir was chosen as a potential host based on its prevalence in the bareroot forest nursery industry and because it is considered to be one of the most susceptible tree species to Pythium damping-off (12). Greenhouse temperatures were maintained at $23 / 18^{\circ} \mathrm{C}$ day/night, with no supplemental lighting. Water was manually applied as needed, usually twice weekly, using a low-pressure sprinkler nozzle. The experiment was conducted three times (trials).

Disease evaluation and statistical methods. The ability of each Pythium isolate to cause damping-off (either preemergence or postemergence) was assessed by recording the number of surviving seedlings in each replicate pot weekly for 4 weeks and comparing counts to the negative control. A subset of seedlings from each isolate and negative control treatment was assayed for pathogen presence by plating onto PARP agar. At 4 weeks, the surviving seedlings were lifted from the soil, washed, and the presence or absence of root lesions $(1=$ necrotic lesions present, $0=$ absent $)$ and taproot length (to the nearest centimeter) was recorded for each seedling. Isolate pathogenicity and virulence were then assessed using seedling count and root lesion data. Pathogenicity, as used here, refers to the qualitative ability of an isolate to cause disease. Any isolate that reduced seedling counts or increased the number of root lesions in comparison to the negative control was characterized as pathogenic. Virulence, as used here, refers to the quantitative, relative ability of each isolate to cause disease. Regardless of their ability to cause root lesions, all isolates that reduced seedling counts by $\geq 25 \%$ were characterized as highly virulent. Isolates that reduced seedling counts by $<25 \%$, in addition to causing root lesions, were characterized as weakly virulent.

For statistical analyses, data for the number of surviving seedlings were converted into proportions (number of seedlings/average number of germinated seedlings in the negative control treatment) for each replicate pot. Similarly, data for the number of seedlings with root lesions were converted into proportions (number of seedlings with root lesions/total number of seedlings) for each replicate pot. Because these data did not meet normal distribution and homogeneity of variance assumptions, even after transformation with the arcsine of the square root, data were analyzed using KruskalWallis and Scheirer-Ray-Hare tests for effects of trial, block, species, and isolate. These methods are nonparametric approaches for comparing ranked data, and are similar to multiway ANOVAs (11). Pairwise comparisons among species, among isolates within species, and among all isolates regardless of species were conducted using specific contrasts. Root length data were analyzed for effects of trial, block, species, and isolate (nested within species) with trial and block as random factors, and species and isolate as fixed factors. All analyses were performed with Minitab Statistical Software (release 15; Minitab Inc., State College, PA) and SAS 9.2 (SAS Institute Inc., Cary, NC).

\section{Results}

Most seed germination occurred within the first 2 weeks after planting. Percent germination in the negative control averaged $76 \%$ (7.6 germinated seeds/10 seeds planted), which was consistent with the seedlot used for the experiment (data not shown). Preemergent damping-off was evident in Pythium-inoculated treatments as nongerminated seeds or as seedlings that did not emerge from the potting media; postemergent damping-off was evident as newly emerged seedlings collapsed and died. Pythium-inoculated treatments that exhibited preemergent damping-off always exhibited postemergent damping-off; therefore no further attempt was made to distinguish between the two in terms of surviving seedling counts. Most damping-off (pre- and postemergent) occurred within the first 3 weeks after planting, with relatively little increase in seedling mortality between 3 and 4 weeks (data not shown). Finally, all Pythium isolates were recovered from root tissue of surviving seedlings at the termination of each trial, and no Pythium was ever isolated from negative control seedlings.

Pythium species varied significantly in their ability to reduce seedling counts $(P<0.001$, Table 2$)$. Eight of the 16 Pythium species tested reduced the mean number of seedlings by at least $25 \%$ in comparison to the negative control $(P \leq 0.040)$ and were therefore characterized as highly virulent pathogens under greenhouse conditions ( $P$. dissotocum, $P$. irregulare, $P$. aff. macrosporum, $P$. mamillatum, $P$. aff. oopapillum, $P$. rostratifingens, $P$. sylvaticum, and $P$. ultimum var. ultimum). $P$. irregulare was the most virulent species, reducing seedling counts by an average 54\% (mean 3.5 seedlings), and $P$. mamillatum was the least virulent species, reducing counts by an average 25\% (mean 5.7 seedlings). The remaining eight Pythium species did not reduce seedling counts in comparison to the negative control and were therefore initially characterized as nonpathogenic under greenhouse conditions. Although a trial effect was observed for 5/16 Pythium species (P. irregulare group IV, $P$. mercuriale, $P$. aff. oopapillum, $P$. ultimum var. ultimum, and $P$. 'vipa'), analyses of each trial separately showed similar results with the eight most virulent species consistently reducing seedling counts (data not shown). No block or interaction effects were observed $(P \geq 0.076)$.

Within each of 10 Pythium species (P. dissotocum, P. irregulare, $P$. aff. macrosporum, $P$. mamillatum, $P$. middletonii, $P$. rostrat-

Table 2. Responses ${ }^{\mathrm{z}}$ of Douglas-fir seedlings inoculated with 16 species of Pythium obtained from soil at three forest nurseries

\begin{tabular}{|c|c|c|c|c|}
\hline Species & No. isolates & Mean no. seedlings (SE) & $\begin{array}{l}\text { Mean percent seedlings } \\
\text { with root lesions (SE) }\end{array}$ & $\begin{array}{l}\text { Mean taproot length } \\
\text { in } \mathrm{cm}(\mathrm{SE})\end{array}$ \\
\hline Control & - & $7.6(0.37) \mathrm{a}$ & $17(4.8) \mathrm{a}$ & $8.4(0.55) \mathrm{a}$ \\
\hline P. dissotocum & 2 & $5.3(0.41)$ & $41(5.1)$ & $7.4(0.31) \mathrm{a}$ \\
\hline P. irregulare & 5 & $3.5(0.26)$ & $43(4.5)$ & $7.3(0.26)$ \\
\hline P. irregulare group III & 3 & $7.1(0.20) \mathrm{a}$ & $40(3.8)$ & $8.3(0.19) \mathrm{a}$ \\
\hline P. irregulare group IV & 3 & $7.6(0.20) \mathrm{a}$ & $39(4.0)$ & $8.7(0.21) \mathrm{a}$ \\
\hline P. aff. macrosporum & 3 & $3.6(0.41)$ & $44(5.6)$ & $7.1(0.43)$ \\
\hline P. mamillatum & 3 & $5.7(0.29)$ & $39(3.9)$ & $7.8(0.22) \mathrm{a}$ \\
\hline P. aff. mercuriale & 1 & $7.9(0.38) \mathrm{a}$ & $45(5.1)$ & $9.1(0.45) \mathrm{a}$ \\
\hline P. middletonii & 2 & $7.1(0.27) \mathrm{a}$ & $32(4.1)$ & $8.3(0.21) \mathrm{a}$ \\
\hline P. aff. oopapillum & 2 & $5.5(0.43)$ & $44(5.4)$ & $7.4(0.34) \mathrm{a}$ \\
\hline$P$. pachycaule & 2 & $7.5(0.26) \mathrm{a}$ & $40(4.3)$ & $8.6(0.28) \mathrm{a}$ \\
\hline P. rostratifingens & 2 & $5.6(0.38)$ & $40(5.7)$ & $7.9(0.30) \mathrm{a}$ \\
\hline P. aff. spiculum & 3 & $6.5(0.28) \mathrm{a}$ & $46(4.2)$ & $7.8(0.21) \mathrm{a}$ \\
\hline P. sylvaticum & 3 & $5.3(0.31)$ & $44(4.4)$ & $7.9(0.23) \mathrm{a}$ \\
\hline P. torulosum & 4 & $7.2(0.24) \mathrm{a}$ & $37(3.3)$ & $8.4(0.19) \mathrm{a}$ \\
\hline P. ultimum var. ultimum & 3 & $4.8(0.30)$ & $42(3.7)$ & $8.1(0.29) \mathrm{a}$ \\
\hline P. 'vipa' & 3 & $7.8(0.20) \mathrm{a}$ & $39(3.8)$ & $8.3(0.25) \mathrm{a}$ \\
\hline
\end{tabular}

${ }^{z}$ Values represent response means for each species and are based on 10 Douglas-fir seeds planted in eight replicate pots in three separate trials arranged according to a random complete block design. $n=24$ to 120 pots depending on the number of isolates for each species. Data were collected 4 weeks after planting into noninfested soilless media (Control) or in media infested with one each of 44 Pythium isolates. Values in a column followed by the same letter are not significantly different from the control treatment at $P>0.05$. 
ifingens, $P$. aff. spiculum, $P$. sylvaticum, $P$. torulosum, and $P$. ultimum var. ultimum), isolates varied in their ability to reduce seedling counts $(P \leq 0.031)$, and $21 / 44$ Pythium isolates reduced the mean number of seedlings in comparison to the negative control ( $P$ $\leq 0.035$, Table 1). The most virulent isolates (e.g., $P$. irregulare isolates 69 and 187, P. aff. macrosporum isolates 10 and 25, and $P$. ultimum var. ultimum isolate ult C1-8) reduced the number of seedlings by 61 to $84 \%$. However, in some cases, not all isolates of a species characterized as pathogenic in the species analyses were similarly virulent on Douglas-fir. For example, $P$. aff. macrosporum isolate 23 did not reduce seedling counts (mean 7.2 seedlings) in comparison to the negative control (mean 7.6 seedlings) and could therefore be considered nonpathogenic. But $P$. aff. macrosporum isolates 10 and 25 , which reduced the number of seedlings to 2.5 and 1.2, respectively, were highly virulent. Conversely, two isolates from species initially characterized as nonpathogenic in the species analyses were found to be pathogenic and were either weakly or highly virulent on Douglas-fir (isolate 36 of $P$. middletonii and isolate 19 of $P$. torulosum), reducing seedling counts by $16 \%$ (6.4 seedlings) and $28 \%$ (5.5 seedlings), respectively. Although seedling counts were observed to vary among isolates within each Pythium species, the variation among isolates $(17 \%)$ was approximately half of the variation observed among species (29\%).

Inoculation with Pythium, regardless of species, always resulted in a greater number of seedlings with necrotic root lesions (total mean $=40 \%)$ than was observed on negative control seedlings $(P \leq$ 0.025 , mean $17 \%$, Table 2). Even seedlings inoculated with a Pythium species that did not significantly reduce seedling survival, such as $P$. irregulare group III or $P$. pachycaule, were consistently more likely to have root lesions than the negative control. Results were similar for individual Pythium isolate analyses (Table 1). Therefore, the eight Pythium species that were initially characterized as nonpathogenic in terms of reducing seedling counts (e.g., $P$. irregulare group III and $P$. pachycaule) were recharacterized as weakly virulent pathogens based on their ability to cause root lesions. Only 8/44 Pythium isolates did not significantly increase the number of root lesions when compared to the negative control $(P \geq$ $0.054)$. All other isolates resulted in a significantly greater number of seedlings with necrotic root lesions $(P \leq 0.045)$. No trial, block, or interaction effects were observed $(P \geq 0.127)$.

Mean taproot length was shorter than the negative control treatment only for those seedlings inoculated with either $P$. irregulare or $P$. aff. macrosporum ( $P \leq 0.001$, Table 2$)$. All other seedlings inoculated with the other 14 Pythium species had taproot lengths similar to those in the negative control $(P \geq 0.140)$. Individual Pythium isolate analyses were similar, with only five isolates having significantly shorter taproots than those in the control treatment $(P<0.003$, Table 1). Significant effects of trial, block, and interaction block were observed $(P<0.001)$. However, analyses within each trial and block separately yielded similar results, with taproot lengths that were consistently similar to those in the negative control regardless of the Pythium isolate tested (data not shown).

\section{Discussion}

This study was conducted to determine the pathogenicity and relative virulence of Pythium species on Douglas-fir seedlings. As a result, 16 Pythium species were characterized as weakly or highly virulent pathogens depending on their ability to reduce seedling survival and to cause root lesions. Although the experiment was conducted in the greenhouse with isolates collected from the soil, the potential certainly exists for these Pythium species to cause disease in the field. Subsequent isolations from Douglas-fir seedling roots in cold storage and from the field at the same nurseries have yielded isolates of $P$. dissotocum, $P$. irregulare, $P$. aff. macrosporum, $P$. mamillatum, $P$. sylvaticum, and $P$. ultimum var. ultimum, which provides evidence for their association with Douglas-fir under nursery conditions. Results are also consistent with previous reports (regional and worldwide) that identify $P$. dissotocum, $P$. irregulare, $P$. mamillatum, $P$. sylvaticum, and $P$. ultimum as forest nursery seedling pathogens $(4,14-17)$. However, field studies are needed to confirm the ability of these Pythium species to cause disease and reduce yield under field conditions in the PNW.

Based on Pythium species isolation frequency data from our previous research (18), the five most virulent, pathogenic species that were also the most prevalent in our forest nursery soil survey in 2008 were $P$. dissotocum (146/900 isolates or $16 \%)$, P. irregulare (27\%), P. aff. macrosporum (9\%), P. sylvaticum (6\%), and P. ultimum var. ultimum (7\%). These species are probably the most likely to pose a risk to production at the three nurseries surveyed. Although at least one isolate each of $P$. aff. oopapillum and $P$. rostratifingens, and two isolates of $P$. mamillatum caused greater than $25 \%$ mortality in this study, these species were not frequently encountered during the survey $(<1 \%$ of Pythium isolates) and are considered a relatively low risk for reducing seedling production. Nevertheless, Hansen et al. (2) found $>70 \%$ of the isolates at one Oregon forest nursery were $P$. mamillatum, indicating that this species can be locally abundant. Two other Pythium species that occurred relatively frequently in our previous survey were $P$. aff. spiculum (6\%) and $P$. 'vipa' (18\%). Neither of these species were characterized as highly virulent pathogens in the present study, but their abundance indicates that nursery soils can contain relatively large numbers of weakly pathogenic or potentially nonpathogenic Pythium species. Therefore, decisions to fumigate or apply fungicides based on soil counts alone may overestimate disease risk.

Nursery-to-nursery variability in Pythium community structure has been documented $(2,15,18)$, and there is a need for fast and reliable DNA-based assays to test for the relative proportion of pathogenic to nonpathogenic (and/or highly virulent to weakly virulent) Pythium species prior to implementation of pathogen control measures. The culture-based methods that are commonly used in the forest nursery industry are comparatively biased in the Pythium species that they detect $(1,18)$. In the 2008 forest nursery soils survey (18), the dilution plate method for assessing Pythium was more likely to detect $P$. irregulare, $P$. sylvaticum, and $P$. ultimum var. ultimum, whereas the baiting methods preferentially detected $P$. dissotocum and P. aff. macrosporum. Both sets of Pythium species were characterized as highly virulent pathogens in the present study; therefore the use of either detection method separately could result in undercounts of highly virulent, pathogenic Pythium populations. Furthermore, both methods detected species and isolates that were only weakly pathogenic or nonpathogenic. As knowledge about the pathogenicity of the different Pythium species in forest nursery soils increases, DNA-based detection methods, such as real-time PCR or multiplex DNA array systems $(1,10,13)$, could reduce this detection bias and would greatly enhance the ability to quickly detect and differentiate between pathogenic and nonpathogenic or highly virulent and weakly virulent species.

Seedlings inoculated with Pythium, regardless of species, were always more likely to have root lesions than those from the negative control treatment. Subsequent attempts to reisolate Pythium from control seedlings were always negative, indicating that the seedlings were not accidentally cross-contaminated. Yet, the greater percentage of lesions on inoculated seedlings indicates the potential for all of the Pythium species tested to affect root health and to be considered as pathogens. Pythium species are frequently considered root "nibblers" (12), and the presence of root lesions could adversely affect seedling health. Longer-term studies are needed to evaluate whether the presence of root lesions caused by weakly virulent Pythium species can negatively affect seedling yield and quality.

Finally, seedling taproot length data were not useful in the evaluation of pathogenicity and virulence of Pythium species to Douglas-fir. Most damage by damping-off pathogens in forest nurseries occurs in the few weeks following germination when the root system is small and the root tissues are still relatively young and succulent (5). After that, obvious damage by Pythium species is rarely apparent in older seedlings unless there is excess water in the soil, in which case root rot can become a problem. In this study, seedlings that survived the initial stage of damping-off may have had a 
root system that was sufficiently robust to tolerate any root lesion development.

The results of this study expand the number of known Pythium species that are pathogenic to seedlings of Douglas-fir. Eight Pythium species were characterized as highly virulent pathogens (P. dissotocum, P. irregulare, P. aff. macrosporum, P. mamillatum, $P$. aff. oopapillum, $P$. rostratifingens, $P$. sylvaticum, and $P$. ultimum var. ultimum) based on their ability to reduce seedling survival and cause root lesions. The other eight Pythium species were characterized as weakly virulent pathogens $(P$. irregulare groups III and IV, $P$. aff. mercuriale, $P$. middletonii, $P$. pachycaule, $P$. aff. spiculum, $P$. torulosum, and $P$. 'vipa') based on their ability to solely cause root lesions without a concomitant significant reduction in seedling survival. In addition to the needs identified above (field validation of pathogenicity and virulence, and development of DNA-based detection methods), future research should address the ability of these species to cause disease in other seedling tree species and evaluate how nursery pest management practices affect Pythium community structure. As fumigation becomes increasingly regulated and targeted for phase-out, more reliance will be placed on management practices that require greater knowledge regarding species identification, pathogenicity, and biology in order to be effective. Information on Pythium species pathogenicity and virulence obtained during this study contributes to this base of knowledge and will facilitate the development of disease control practices that more actively target pathogen species of interest.

\section{Acknowledgments}

We gratefully acknowledge the assistance of Val Fieland and the Nik Grunwald lab in the identification of Pythium isolates. We also acknowledge the technical assistance of Duncan Kroese. Financial support was provided by the Pacific Area Wide Pest Management Program for Methyl Bromide Alternatives.

\section{Literature Cited}

1. Dumroese, R. K., and James, R. L. 2005. Root diseases in bareroot and container nurseries of the Pacific Northwest: Epidemiology, management, and effects on outplanting performance. New For. 30:185-202.

2. Hansen, E. M., Myrold, D. D., and Hamm, P. B. 1990. Effects of soil fumigation and cover crops on potential pathogens, microbial activity, nitrogen availability, and seedling quality in conifer nurseries. Phytopathology 80:698-704.

3. Hildebrand, D. M., Stone, J. K., James, R. L., and Frankel, S. J. 2004.
Alternatives to preplant soil fumigation for Western forest nurseries. USDA Forest Service, Pacific Northwest Research Station. Gen. Tech. Report PNW-GTR-608.

4. James, R. L. 2002. Effects of spring applications of dazomet on root diseases and performance of Douglas-fir and western white pine transplants. USDA Forest Service Nursery, Coeur d'Alene, Idaho. For. Health Prot. Rep. 02-9.

5. James, R. L. 2012. Damping-off. Pages 115-116 in: Forest Nursery Pests. M. M. Cram, M. S. Frank, and K. M. Mallams, tech. coords. USDA-Forest Service. Agric. Handb. No. 680.

6. James, R. L., Knudsen, G. R., and Morra, M. J. 2004. Preplant soil treatment effects on production of Douglas-fir seedlings at the USDA Forest Service Nursery, Coeur d'Alene, Idaho. For. Health Prot. Rep. 04-10.

7. James, R. L., Metzger, S., and Gilligan, C. J. 1990. Effects of soil fumigation on conifer seedling production at the USDA Forest Service Nursery, Coeur d'Alene, Idaho. For. Pest Manag. Rep. 90-11.

8. Kannwischer, M. E., and Mitchell, D. J. 1978. The influence of a fungicide on the epidemiology of black shank of tobacco. Phytopathology 68:17601765 .

9. Linderman, R. G., and Zeitoun, F. 1977. Phytophthora cinnamomi causing root rot and wilt of nursery-grown native western azalea and salal. Plant Dis. Rep. 61:1045-1048.

10. Schroeder, K. L., Okubara, P. A., Tambong, J. T., Lévesque, C. A., and Paulitz, T. C. 2006. Identification and quantification of pathogenic Pythium spp. from soils in eastern Washington using real-time polymerase chain reaction. Phytopathology 96:637-647.

11. Sokal, R. R., and Rohlf, F. J. 2012. Biometry. 4th ed. W. H. Freeman and Company, New York.

12. Sutherland, J., and Dennis, J. 1992. Pythium water mould in British Columbia forest nurseries. Seed Seedling Ext. Topics 5:9-10.

13. Tambong, J. T., de Cock, A. W. A. M., Tinker, N. A., and Lévesque, C. A. 2006. Oligonucleotide array for identification and detection of Pythium species. Appl. Environ. Microbiol. 72:2691-2706.

14. Vaartaja. 1967. Damping-off pathogens in S. Australia. Phytopathology 57:765-768.

15. Vaartaja. 1968. Pythium and Mortierella in soils of Ontario forest nurseries. Can. J. Microbiol. 14:265-269.

16. Vaartaja, O. 1975. Pythium sylvaticum in Canadian forest nurseries. Can. Plant Dis. Surv. 55:101-102.

17. Warcup, J. H. 1952. Effect of partial sterilization by steam or formalin on damping-off of sitka spruce. Trans. Br. Mycol. Soc. 35:248-262.

18. Weiland, J. E. 2011. Influence of isolation method on recovery of Pythium species from forest nursery soils in Oregon and Washington. Plant Dis. 95:547-553.

19. Weiland, J. E., Leon, A. L., Edmonds, R. L., Littke, W. R., Browning, J. E., Davis, A., Beck, B. R., Miller, T. W., Cherry, M. L., and Rose, R. 2011. The effects of methyl bromide alternatives on soil and seedling pathogen populations, weeds, and seedling morphology in Oregon and Washington forest nurseries. Can. J. For. Res. 41:1885-1896. 